\title{
Hvorfor varierer tvangsbruken, og hva kan vi gjøre med det?
}

\author{
Både gjennomføring og dokumentasjon av bruk av tvang innen psykisk helsevern varierer i altfor stor grad. \\ Årsakene til varierende tvangsbruk er mange, og vi mangler kunnskap.
}

Det er gledelig at rettssikkerheten til mennesker med psykisk sykdom opptar fagpersoner utenfor klinisk virksomhet. Marie Hovland presenterer i denne utgaven av Tidsskriftet juridiske betraktninger om hvorfor tvangsbruk varierer rundt omkring i landet (1). Undertegnede er invitert av Tidsskriftet til å kommentere artikkelen. Jeg vil først kommentere Hovlands punkter, før jeg diskuterer andre mulige årsaker til variasjon i tvangsbruk.

\section{Alvorlig sinnslidelse \\ Hovland påpeker at psykoselidelser side- stilles med ikke-psykotiske tilstander, eksempelvis alvorlig spiseforstyrrelse og alvorlig personlighetsforstyrrelse. En per- sons fungering og realitetsvurdering kan være så nedsatt at tilstanden rent klinisk ligner en psykose. Ettersom klinikere må gjøre nettopp kliniske vurderinger, vil ikke pasientens tilstand nødvendigvis tilsvare det juridiske begrepet «alvorlig sinns- lidelse».}

\section{Samtykkekompetanse}

Hovland berører ikke hvorvidt vurdering av samtykkekompetanse virker inn på tvangsbruk. I pasient- og brukerrettighetsloven kapittel 4a, som regulerer tvangsbruk mot pasienter i somatisk helsetjeneste (2), står det at vedtak skal fattes dersom pasienten ikke er samtykkekompetent og motsetter seg intervensjoner. Hvis pasienten ikke motsetter seg intervensjoner, fattes ikke vedtak. I psykisk helsevern er det neppe enhetlig praksis for hva man gjør når pasienten ikke motsetter seg innleggelse, men samtidig mangler samtykkekompetanse. Pasienter som er katatone eller svært forvirrede, vil kunne underkaste seg undersøkelse og innleggelse uten aktiv protest. Men vil vedkommendes rettssikkerhet være ivaretatt under en frivillig innleggelse? Praksis vil noen steder være at pasienter som ikke aktivt samtykker, tas imot under tvang for nettopp å sikre at pasientens klagemuligheter ivaretas. En juridisk betenkning rundt denne problemstillingen er ønsket.

\section{Selvmordsfare}

Selvmordsfare som innleggelsesårsak foreligger slik Hovland beskriver. Det er ikke lovstridig å ta sitt eget liv, men i psykisk helsevern vil man legge til grunn at det er en alvorlig depresjon eller annen sykdom som er årsaken til et dødsønske, inntil det motsatte er bevist. Helsepersonells plikt til å yte øyeblikkelig hjelp (3) og nødrettsbetraktninger (4) er motivasjonen for å tolke loven slik at man sikrer at ingen etterlates i livsfare. At slik praksis ikke nødvendigvis er i tråd med lovens intensjon er klart, men det skal likevel mye til for å endre slik praksis. Å hindre upsykotiske mennesker fra å ta sitt eget liv kan selvsagt oppfattes som en krenkelse av deres autonomi, men i en travel klinisk hverdag vil filosofiske og etiske refleksjoner komme sekundært til livreddende tiltak.

Det er også flere eksempler på at helsepersonell har fått reaksjoner fra tilsynsmyndighetene når det $i$ etterkant viser seg at

\section{«Psykisk helsevern- loven er i stor grad et lovverk som tar individets perspektiv»}

pasienter har tatt sitt eget liv. Skal praksis endres, må det fra ledelsesnivå legges til rette for etiske refleksjoner og beslutningsstøtte for helsepersonell som stadig står i slike dilemmaer.

\section{Farekriteriet}

At fare for andre blir brukt som innleggelseskriterium uavhengig av om hovedkriteriet er oppfylt, er en praksis klinikere vil ta avstand fra på prinsipielt grunnlag. Likevel kan det skje fra tid til annen. Psykisk helsevernloven er i stor grad et lovverk som tar individets perspektiv, noe som er i tråd med vår norske, individualistiske kultur. Generelt spiller hensynet til andre mindre rolle i Norge enn for eksempel i østlige kulturer (5).

Likevel viser praksis at man fra tid til annen lar hensynet til eksempelvis pårørende veie tungt når det foreligger voldsutøvelse eller trusler. Selv den sittende regjeringen ønsker å innføre tvungen behandling i inntil tre år for mennesker som har såkalt plagsom atferd (6). Det er foreslått at personer med plagsom og gjentatt kriminell atferd skal kunne idømmes særreaksjonen «dom til behandling» - selv om det ikke vurderes som at den psykiske sykdommen er alvorlig nok for innleggelse til tvungent psykisk helsevern. Jurister og fagfolk innen psykisk helsevern er imot lovforslaget nettopp fordi kriminalitet ikke oppfattes som en psykisk lidelse som kan behandles. Men når sentrale politikere kjenner behovet for å gjøre noe med mennesker som plager andre, er det ikke så merkelig at innleggelse under tvungent vern kan forekomme - selv om man er klar over at hovedvilkåret ikke er oppfylt.

\section{Mange grunner til ulik tvangsbruk} For å få til ønsket reduksjon og kvalitetssikring trenger vi kunnskap om praksis. Noe av årsaken til at statistikken viser variabel bruk av tvangsinnleggelser skyldes at man ikke har tilfredsstillende dokumentasjons- og rapporteringssystemer. Manglene kan likevel ikke forklare den store variasjonen alene.

Press på døgnplasser etter nedbygging av institusjonsplasser over år, varierende tilgang til lavterskeltilbud og ambulante tjenester og andre geografiske ulikheter i det prehospitale tilbudet til psykisk syke er faktorer som bidrar til variasjonen i bruk av tvang ved innleggelser (7). En ny norsk studie har vist at kompetanse hos innleggende instans er en faktor som bidrar til variasjon i forekomsten av tvanginnleggelser (8).

Av egen erfaring kan det dessuten virke som innleggende lege av og til bruker tvang til tross for at frivillighet kunne vært mulig, kun for å sikre en pasient en plass i en akutt døgnenhet. Dersom man presenterer innleggelsen som frivillig, kan den oppleves som mindre prekær.

Et siste punkt er kontrollkommisjonenes rolle. Som klinikere vet vi at det er stor variasjon i praksis fra kontrollkommisjon til kontrollkommisjon. Kontrollkommisjoner utøver skjønn juridisk, men kanskje med en (for stor?) grad av pragmatisme enkelte steder. Det er selvsagt en fordel at kontrollkommisjonene kjenner institusjonene, men det er bekymringsfullt om for godt kjennskap fra tid til annen kan komme i veien for pasientens rettssikkerhet.

Hovland tar opp viktige temaet i sin kronikk, men årsaken til i variasjon i bruk av tvang ved innleggelser i psykisk helsevern er trolig flere og mer komplekse enn det som kan forklares ut fra ulik lovfortolkning.

Anne Kristine Bergem

akbergem@me.com 
Anne Kristine Bergem (f. 1969) er leder av Norsk psykiatrisk forening og fagrådgiver i Rådet for psykisk helse. Hun er tidligere overlege/avdelingsoverlege ved Regional sikkerhetsavdeling Helse Sør-Øst.

Forfatter har fylt ut ICMJE-skjemaet og oppgir ingen interessekonflikter.

\section{Litteratur}

1. Hovland M. Rettstryggleik for den psykisk sjuke. Tidsskr Nor Legeforen 2016: 136: 1099-101.

2. Lov om pasient- og brukerrettigheter (pasientog brukerrettighetsloven). Kapittel 4 A. Helsehjelp til pasienter uten samtykkekompetanse som motsetter seg helsehjelpen mv. https://lovdata.no/ dokument/NL/lov/1999-07-02-63/KAPITTEL 5\# KAPITTEL 5 (28.5.2016)

3. Lov om helsepersonell m.v. (helsepersonelloven) kapittel 2 \& 7. https://lovdata.no/dokument/NL/lov/ 1999-07-02-64/KAPITTEL_2\#KAPITTEL_2 (28.5.2016).

4. Lov om straff (straffeloven) kapittel $3 \S 17$ https://lovdata.no/dokument/NL/lov/2005-05-2028/KAPITTEL_1-3\#KAPITTEL_1-3 (28.5.2016).

5. Trompenaars F. Hampden-Turner C. Riding the waves of culture. Understanding cultural diversity in business. London: Intercultural Management Publishers NV, 1997

6. Prop. 122 L (2014-2015). Endringer i straffeloven 2005 mv. (strafferettslige særreaksjoner m.m.). www.regjeringen.no/no/dokumenter/prop.-122-l20142015/id2412699/?ch=3 (28.5.2016).

7. Nyttingnes O, Elvemo O, Gaarder P et al. Frivillighet før tvang: tiltak for å redusere omfang av tvangsinnleggelser til psykisk helsevern. Oslo: Rådet for psykisk helse, 2010

8. Fuglseth NLD, Gjestad R, Mellesdal L et al. Factors associated with disallowance of compulsory mental healthcare referrals. Acta Psychiatr Scand 2016; 133: 410-8.

Mottatt 28.5. 2016 og godkjent 13.6. 2016. Redaktør: Ketil Slagstad.

> Se også side 1099

Publisert først på nett.

\section{På tide å innføre spesialisteksamen}

Når jeg tenker tilbake på min egen spesialistutdanning, slår det meg at man praktisk talt kunne bli spesialist uten å måtte dokumentere bestemte krav til kunnskap og ferdigheter. Så lenge man deltok i det daglige arbeidet $\mathrm{i}$ de godkjente institusjonene $\mathrm{i}$ et gitt antall år, var det automatikk i å bli godkjent spesialist. Nå vet enhver at det kan være store forskjeller i kunnskapsnivået blant våre leger. Faglig nivå er avhengig av mange faktorer, blant annet interesse for faget, evnen til å lære og kvaliteten på utdanningen. Men det er stort sett ingen kvalitetskontroll på slutten av spesialistutdanningen, og det er vel ekstremt sjelden at noen blir oppsagt eller nektet spesialistgodkjenning.

I flere europeiske land kreves bestått spesialisteksamen for å bli spesialist i hud- og veneriske sykdommer. Norge er et av de få landene som ikke krever spesialisteksamen. Min erfaring som professor i både Norge og Sveits har overbevist meg om at bestått spesialisteksamen bør innføres som spesialistkrav i Norge. I Sveits er det en meget omfattende og vanskelig spesialisteksamen. Assistentlegene under utdanning starter tidlig å forberede seg til eksamen. De vet at kravene er store. Derfor har de også et meget høyt kunnskapsnivå når de er ferdige med hele forløpet. Noen vil hevde at det etter medisinsk embetseksamen må være slutt på eksamener. Men vi skylder samfunnet og våre pasienter at vi har et godt dokumentert kunnskapsnivå for å få spesialistgodkjenning. Dette var grunnlaget for medisinsk embetseksamen og bør også gjelde for retten til å kalle seg spesialist.

\section{Lasse R. Braathen}

lasse.r.braathen@bluewin.ch

Lasse R. Braathen (f. 1942) er professor emeritus ved Medisinsk fakultet, Universitetet i Bern, Sveits.

Ingen oppgitte interessekonflikter.

Mottatt 26.5. 2016 og godkjent 31.5. 2016. Redaktør: Ketil Slagstad.

Publisert først på nett. 